\title{
О тибетском и монгольском ксилографических изданиях «Повести о Лунной кукушке» (по материалам Национального музея Тувы и архива КалмНЦ РАН)"
}

\author{
Деляи Н. Музраева \\ Калмыцкий научный центр Российской академии наук, Российская Федерация, \\ Рита П. Сумба \\ Национальный музей им. Алдан-Маадыр Республики Тыва, Российская Федерация
}

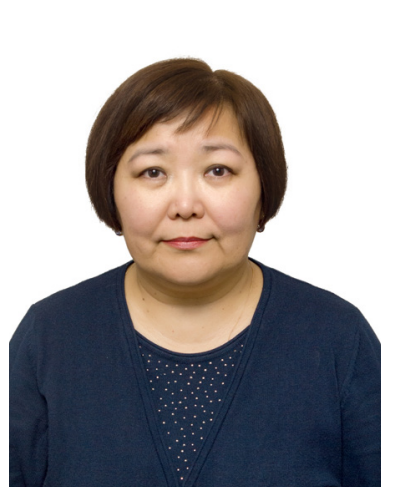

В статье описывается один из буддийских текстов, имеющих фабульную основу, получивщий широкое распространение в среде монголов, бурят, калмыков, известный также тувинцам. Это хорошо известное в монголоведении сочинение с кратким названием «Повесть о Лунной кукушке» (1737). О том, что этот памятник был известен тувинским буддистам, свидетельствует ксилографическое издание этого сочинения на тибетском языке, хранящееся ныне в фондах Национального музея им. Алдан-Маадыр Республики Тыва.

Тибетский ксилограф из музея Тувы озаглавлен «Повесть о птице, преисполненной мыслью о достижении просветления, прозванной Лунная кукушка с голубой шеей, известная под названием „Украшение слуха тех, кто познал, что все предметы материального мира не имеют сущности “» (тиб. Byang chub kyi sems mnga' ba'i bya mgrin sngon zla ba rtogs pa brjod pa 'khor ba mtha' dag la snying po med par mthong ba rnams kyi rna rgyan ces bya ba bzhugs so). Ксилографическое издание на монгольском языке из архива КалмНЦ РАН имеет название «Повесть о птице-бодхисаттве по имени Лунная кукушка с голу-

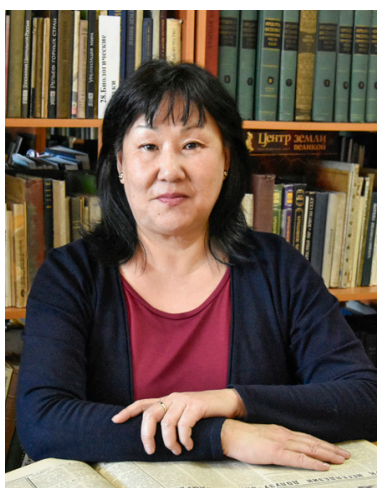
бой шеей, именуемая «Украшением слуха познавших, что материальный мир не имеет

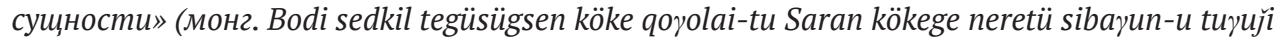
orčilang-un bükün-i jüirüken ügei kemen medegčid-ün čikin-ü čimeg).

Дается описание ксилографического издания в Туве в сопоставлении с текстом монгольского перевода по ксилографу из фондов КалмНЦ РАН.

Ключевые слова: буддизм; письменный источник; буддийская литература; Тува; Калмыкия; музей; архив; ксилографы; Повесть о Лунной кукушке; тибетский язык; монгольский язык

"Исследование проведено в рамках государственной субсидии - проект «Устное и письменное наследие монгольских народов России, Монголии и Китая: трансграничные традиции и взаимодействия» (регистрационный номер АААА-А19-119011490036-1).

\section{Для цитирования:}

Музраева Д. Н., Сумба Р. П. О тибетском и монгольском ксилографических изданиях «Повести о Лунной кукушке» (по материалам Национального музея Тувы и архива КалмНЦ РАН) [Электронный ресурс] // Новые исследования Тувы. 2019, № 4. URL: https://nit.tuva.asia/nit/article/view/886 (дата обращения: дд.мм.гг.). DOI: 10.25178/ nit.2019.4.8

Музраева Деляш Николаевна - кандидат филологических наук, доцент, ведущий научный сотрудник, заведующий отделом монгольской филологии, Калмыцкий научный центр Российской академии наук. Адрес: 358000, Россия, г. Элиста, ул. И. К. Илишкина, д. 8. Тел.: +7 (917) 680-80-21. Эл. адрес: deliash@mail.ru

ORCID ID: 0000-0002-8619-9369

Сумба Рита Петровна - научный сотрудник отдела культуры, искусства и религии Национального музея им. Алдан-Маадыр Республики Тыва. Адрес: 667000, Россия, г. Кызыл, ул. Титова, д. 30. Тел.: +7 (923) 384-32-91. Эл. адрес: risu1232001@yahoo.de ORCID ID: 0000-0002-6296-2809

Muzraeva Delyash Nikolaevna, Candidate of Philology, Leading Research Associate, Head of Department of Mongolian Philology, Kalmyk Scientific Center of the Russian Academy of Sciences. Postal address: 8 Ilishkin St., 358000 Elista, Russian Federation. Tel.: +7 (917) 680-80-21. E-mail: deliash@mail.ru

Sumba Rita Petrovna, Research Associate, Department of Culture, Science and Religion, Aldan Maadyr National Museum of the Tuva Republic. Postal address: 30 Titov St., 667000 Kyzyl, Russian Federation. Tel.: +7 (923) 384-32-91. E-mail: risu1232001@yahoo.de 


\title{
'The Tale of the Moon Cuckoo': \\ Tibetan- and Mongolian-language xylographic editions revisited (a case study of materials stored in the National Museum of the Tuva Republic and the Archive of Kalmyk Scientific Center of the RAS)
}

\author{
Delyash N. Muzraeva \\ Kalmyk Scientific Center of the Russian Academy of Sciences, Russian Federation, \\ Rita P. Sumba \\ Aldan-Maadyr National Museum of the Tuva Republic, Russian Federation
}

\begin{abstract}
The article describes one Buddhist text with a plot basis widely spread among the Mongols, Buryats, Kalmyks, and also known to the Tuvans. This composition is the well-known essay 'The Tale of the Moon Cuckoo'. The fact that this monument was known to Tuvan Buddhists is indicated by a Tibetan-language xylographic edition of this work (code 3-96// 3676/378) stored in the Aldan Maadyr National Museum of the Tuva Republic.

The mentioned Tibetan-language xylograph is titled 'The Tale of the Bird Aspiring after Enlightenment, Nicknamed the BlueNecked Moon Cuckoo, and Known as 'Delight to the Hearing of Those Who Have Conceived That All Objects of the Material World Have No Essence' (Tib. Byang chub kyi sems mnga' ba'i bya mgrin sngon zla ba rtogs pa brjod pa 'khor ba mtha' dag la snying po med par mthong ba rnams kyi rna rgyan ces bya ba bzhugs so). The Mongolian-language xylographic edition from the Archive of the Kalmyk Scientific Center of the Russian Academy of Sciences bears the title 'The Tale of the Bird-Bodhisattva Named the Blue-Necked Moon Cuckoo, Entitled 'Delight to the Hearing of Those Who Have Conceived That the Material World

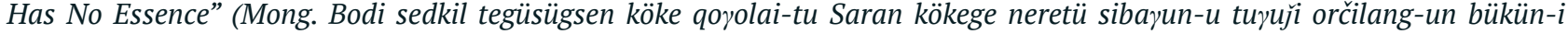
jirüken ügei kemen medegčid-ün čikin-ü čimeg).

The paper provides a description of the Tuva-based woodblock publication and compares it with the Mongolian-language translation according to the xylograph from Kalmyk Scientific Center of the RAS.
\end{abstract}

Keywords: Buddhism; written sources; Buddhist literature; Tuva; Kalmykia; museum; archive; xylographs; Tale of the Moon Cuckoo; Tibetan language; Mongolian language

The reported study was funded by government subsidy - project name 'Oral and Written Heritage of the Mongolic Peoples of Russia, Mongolia and China: Cross-Border Traditions and Interactions' (registration number AAAA-A19-119011490036-1).

\section{For citation:}

Muzraeva D. N. and Sumba R. P. 'The Tale of the Moon Cuckoo': Tibetan- and Mongolian-language xylographic editions revisited (a case study of materials stored in the National Museum of the Tuva Republic and the Archive of Kalmyk Scientific Center of the RAS). The New Research of Tuva. 2019, № 4. URL: https://nit.tuva.asia/nit/article/view/886 (access date ...). DOI: 10.25178/ nit.2019.4.8

\section{Введение}

Культуре народов России, традиционно исповедующих буддизм (калмыков, бурят, тувинцев), присущи общие черты, затрагивающие не только ритуальную сторону религиозных обрядов, повседневную литургическую службу в буддийских храмах, но и систему религиозного образования, а также проповедническую деятельность буддийских священнослужителей, заботившихся о популяризации своего учения среди мирян. В последнем из указанных видов деятельности буддийского духовенства важная роль отводилась письменным источникам. Изучение состава и содержания религиозных текстов, имевших хождение в ламской среде, сохранившихся к началу XXI в. и хранящихся ныне в книжных фондах Калмыкии и Тувы (Бичелдей, 2011; Мирзаева, 2018; Мирзаева, Тувшинтугс, 2019; Музраева, 2018; Музраева, Сумба, 2019: Электр. ресурс; Сумба, 2019: Электр. ресурс; см. также обзор Bakaeva, 2014), будет способствовать выявлению общего корпуса текстов, приемов проповеднической деятельности, а также постановки учебного дела при буддийских монастырях.

При этом необходимо дать описание образцов текстов, имеющих фабульную основу, получивших широкое распространение у монголов, бурят, калмыков, известные тувинцам. Одним из таких сочи- 
нений является хорошо известное в монголоведении под кратким названием сочинение «Повесть о Лунной кукушке». Один из образцов монгольской версии (Bodi sedkil) в настоящее время хранится в Научном архиве Калмыцкого научного центра РАН (далее - КалмНЦ РАН). В фондах Национального музея Республики Тыва имеется тибетский ксилограф «Повести...», изданный в тибетском монастыре Дрепунг (Byang chub). Перевод на русский язык монгольской версии был осуществлен в 2004 г. (Повесть о Лунной кукушке, 2004). О тибетской версии в отечественной востоковедческой литературе имеется не так много сведений. В данной публикации предполагается дать описание известных изданий текста этого памятника.

В данной статье впервые дается описание ксилографического издания памятника «Повесть о Лунной кукушке» на тибетском языке, сохранившегося в Туве, в сопоставлении с текстом монгольского перевода по ксилографу из фондов КалмНЦ РАН, а также с английским переводом Геше Вангьяла ${ }^{1}$ (1901-1983). Подобная публикация позволит популяризировать интереснейший памятник, имеющий более чем двухсотлетнюю историю, хорошо известный в буддийском мире, в востоковедческих кругах, будет способствовать дальнейшему его изучению, подготовке сводного текста тибетского оригинала и его переводов.

Источниковой базой послужили тибетское ксилографическое издание Byang chub kyi sems mnga' ba'i bya mgrin sngon zla ba 'i rtogs pa brjod pa 'khor ba mtha' dag snying po med par mthong ba rnams kyi rna rgyan zhes bya ba bzhungs so ('Повесть о птице, преисполненной мыслью о достижении просветления, по имени Лунная кукушка с голубой шеей, именуемая «Украшением слуха тех, кто познал, что все предметы сансары не имеют сущности»') (шифр 3-96 // 3676/378. 133 л., размер листов 54,5х8,5 см, размер текста 49,5х8 см), хранящееся в фонде Национального музея Республики Тыва (Byang chub), а также бурятский

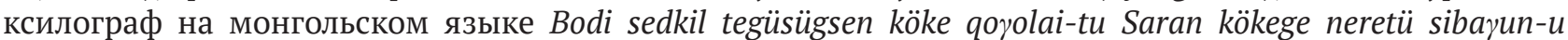
tuүuǰi orčilang-un bükün-i jürüken ügei kemen medegčid-ün čikin-ü čimeg kemekü orusiba ('Повесть о птицебодхисаттве по имени Лунная кукушка с голубой шеей, именуемая «Украшение слуха познавших, что материальный мир не имеет сущности»') (шифр Ф-8 (Фонд редких рукописей), опись 1, ед. хр. 194) из Научного архива КалмНЦ РАН (Bodi sedkil).

\section{Сведения из колофонов об авторе и переводчике}

Автором данного сочинения является Дагпу Лобсан-Данби-Джалцан ${ }^{2}$ (1714-1762). Согласно колофону, сочинение, представляющее собой его «тайную» биографиюз, было записано по просьбе его учеников. Год его создания - 1737.

Отметим, что обращение к текстам данного памятника позволяет сфокусировать внимание на природе особых способностей, которыми были наделены буддийские адепты и которые они применяли в практике медитации с целью совершенствования интеллектуального потенциала.

На монгольский язык это сочинение было переведено в 1780 г. известным литератором XVIII в. Дай гуши ${ }^{4}$ Агвандампилом (Агванданпэлом) (1700-1780) (Повесть о Лунной кукушке, 2004: 28-33).

Монгольский перевод был осуществлен по повелению одного из влиятельных лам Внутренней Монголии Джанджа-хутухты Ролби-Дордже (Рольбий-Дорчжэ) (1717-1786) $)^{5}$ одного из самых известных представителей линии перерождений в школе Гелуг во Внутренней Монголии. Именно

\footnotetext{
${ }^{1}$ Геша Вангьял (тиб. ngag dbang dbang rgyal) - известный калмыцкий буддийский монах. В 1923-1935 гг. по рекомендации Агвана Доржиева - наставника и доверенного лица Далай-ламы XIII, был направлен в Тибет и проходил обучение в монастыре Дрепунг Гоманг в Лхасе, являющемся одним из трех главных монастырей школы Гелуг, где спустя два года защитил степень геше. В 1955 г. был вынужден уехать в США, где в 1958 г. основал буддийский монастырь, в котором прослужил вплоть до своей кончины. Геше Вангьял - автор ряда переводов буддийских сочинений; среди его учеников известные буддологи Р. Турман, Дж. Хопкинс и др.

${ }^{2}$ Дагпу Лобсан-Данби-Джалцан (тиб. stag-phu-ba blo-bzang bstan-pa’i rgyal-mtshan) - один из наиболее известных тибетских воплощенных лам линии преемственности Дагпу; упоминания о нем в сочинениях современников, цитирование «Повести ...» в трудах более поздних тибетских и монгольских авторов свидетельствуют о нем как о незаурядной личности, весьма просвещенном буддийском деятеле средневековья (Повесть о Лунной кукушке, 2004: 18-22).

${ }^{3}$ В тибетской традиции принята классификация, согласно которой различают «внешнюю» биографию (тиб. phyi'i rnam thar), а также «внутреннюю» (тиб. nang gi rnam thar) и «тайную» (тиб. gsang ba'i rnam thar) (Востриков, 1962: 112).

${ }^{4}$ гуши (от кит. го ши 'государственный наставник' - высший титул, который мог получить лама во времена маньчжурской династии Цин (1644-1912) в Китае). Монголы стали использовать форму «гуши» или «дайгуши» в качестве почетного именования переводчика буддийских текстов (см.: Успенский, 2011: 107-109).

${ }^{5}$ О нем см. Успенский, 2011: 17, 105-107 и др.
} 
под руководством Джанджа Ролби-Дордже в период с 1742 г. по 1749 г. велась работа по переводу на монгольский язык и изданию второй части буддийского канона Данджура (Монголын уран зохиолын тойм, 1977: 385-386; Цэрэнсодном, 1987: 314-316). Примечательно, что столь крупномасштабное мероприятие Ролби-Дордже счел необходимым предварить составлением тибетско-монгольского терминологического словаря «Источник мудрецов» (крат. тиб. Dag yig mkhas pa'i 'byung gnas; монг. Merged yarqu-yin oron) (Монголын уран зохиолын тойм, 1976: 385). В этой работе также принимал участие Дай гуши Агвандампил (там же: 385-386).

\section{Из истории изучения памятника}

Многие вопросы изучения рассматриваемого памятника были освещены в зарубежной и отечественной востоковедной литературе (Tibetische Handschriften und Blockdrucke, 1981; Повесть о Лунной кукушке, 2004 и мн. др.).

Описание двух ксилографов хотелось бы дополнить сведениями о китайских изданиях с аналогичным названием. Речь идет о сочинении известного литератора Внутренней Монголии В. Инжинаша (1837-1892), известном под названием «Шастра лунной кукушки» (монг. Saran kököge-yin šastir). Как пишет известный монголовед Л. Г. Скородумова, в этом романе, созданном в 1854 г., повествуется о детских и юношеских годах главного героя по имени Пу юй (Уюй), наследника состоятельного рода, которые прошли в богатом аристократическом китайском доме (Скородумова, 2017: 84). В сочинении описываются игры, романтические взаимоотношения главного героя с тремя сестрами и другими родственницами. При этом исследовательница отмечает, что у Инжинаша нет никакой религиозной подоплеки. Совпадение же в названиях («Лунная кукушка») было вызвано тем, что в Южной Монголии хорошо был известен сюжет буддийского повествования о Лунной кукушке (там же).

История перевода тибетского памятника на монгольские языки тесно связана с деятельностью монгольских, калмыцких и бурятских священнослужителей. То, что калмыки вновь и вновь обращались к этому источнику, не случайно. Здесь хотелось бы сказать несколько слов о переводе известного калмыцкого буддийского священнослужителя Геше Вангъяла, выполненного им с тибетского на английский язык. Факт создания перевода Геше Вангъялом хорошо известен, но мало исследований в отечественном востоковедении, посвященных этому труду. Этот перевод, выполненный в 1950-е гг., вышел в свет в 1982 г. в Нью-Йорке (Geshe Wangyal, 1982). В предисловии к переводу автор пишет, что сочинение «Принц, превратившийся в кукушку: история освобождения» (“Тhe Prince Who Became a Cuckoo: A Tale of Liberation”) - это не просто описание истории жизни царевича Дхармананды, а также последующей жизни в облике кукушки, но и рассказ о том, как практиковать буддизм, используя специальные приемы, которые практикуются Сутраяной и Тантраяной тибетского буддизма (там же: vii). Автор перевода обращает внимание на то, что, читая эту книгу, можно ознакомиться со всеми стадиями этой практики (там же).

Геше Вангьял своим трудом перенес на американскую почву традицию передачи классического тибетского текста, излагающего основные постулаты буддийского учения в ХХ в., тем самым сохранил и создал условия для его популяризации в Америке и Европе.

\section{Краткое содержание текста «Повести...»}

В «Повести ...» дается описание видений и снов, которые являлись автору - Дагпу Лобсан-Данби-Джалцану, начиная с детского возраста. Из этих фрагментарных эпизодов, записанных и выстроенных последовательно, сложилось повествование, в котором описывались события одного из предшествовавших перерождений тибетского автора. Сочинение с подобной занимательной фабулой не могло не найти отклика со стороны читателей и слушателей. Первыми были ученики, по просьбе которых и была записана история индийского царевича, в которого в одной из прошлых жизней воплощался Дагпу.

В повести главным действующим лицом является индийский царевич Дхармананда (тиб. chos kyi dga' ba; монг. Nom-un bayasqulang 'Радость учения'), который обучившись практике «переноса сознания», сумел превратиться в кукушку (букв. «войти в тело» кукушки). В силу козней приближенного сановника, он не смог обернуться вновь человеком и последний отрезок жизни оставался кукушкой. Будучи в облике птицы, сумел внять наставлениям божеств, которые являлись к нему в образе людей и животных, проникся Учением Будды и, вплоть до своей кончины, стал проповедовать его среди зверей и птиц. 


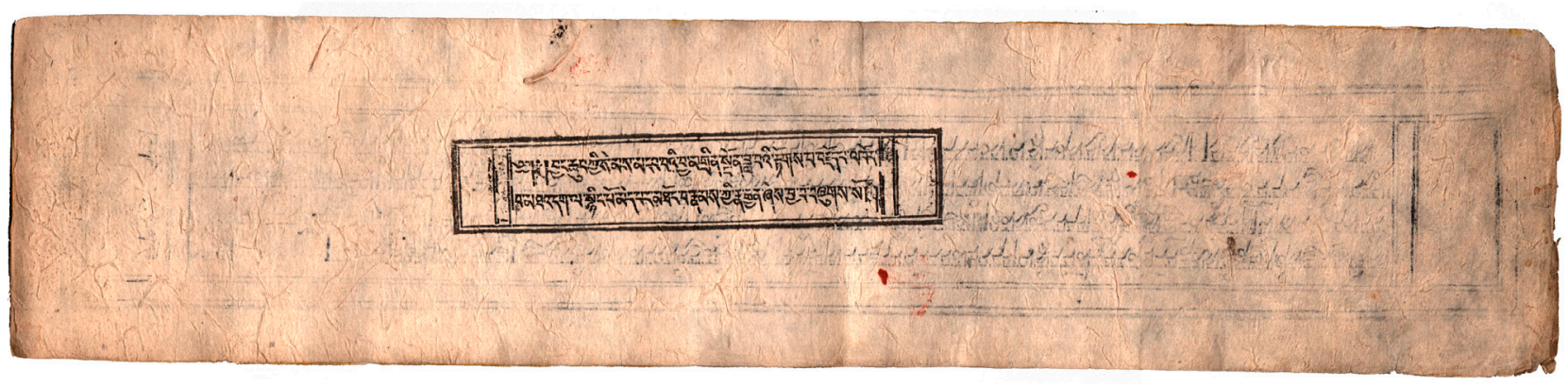

Фото 1. Титульный лист ксилографа на тибетском языке из Национального музея Тувы (шифр 3-96 // 3676/378). Photo 1. The title page of a xylograph in Tibetan from the National Museum of Tuva (code 3-96// 3676/378).

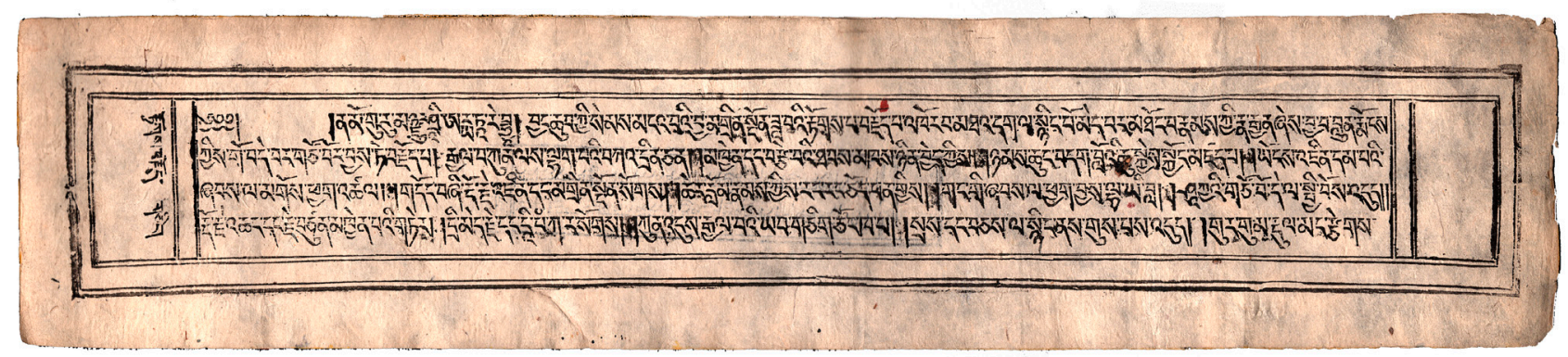

Фото 2. Лист 16 ксилографа на тибетском языке из Национального музея Тувы. Photo 2. Sheet $1 b$ of a Tibetan xylograph from the National Museum of Tuva.

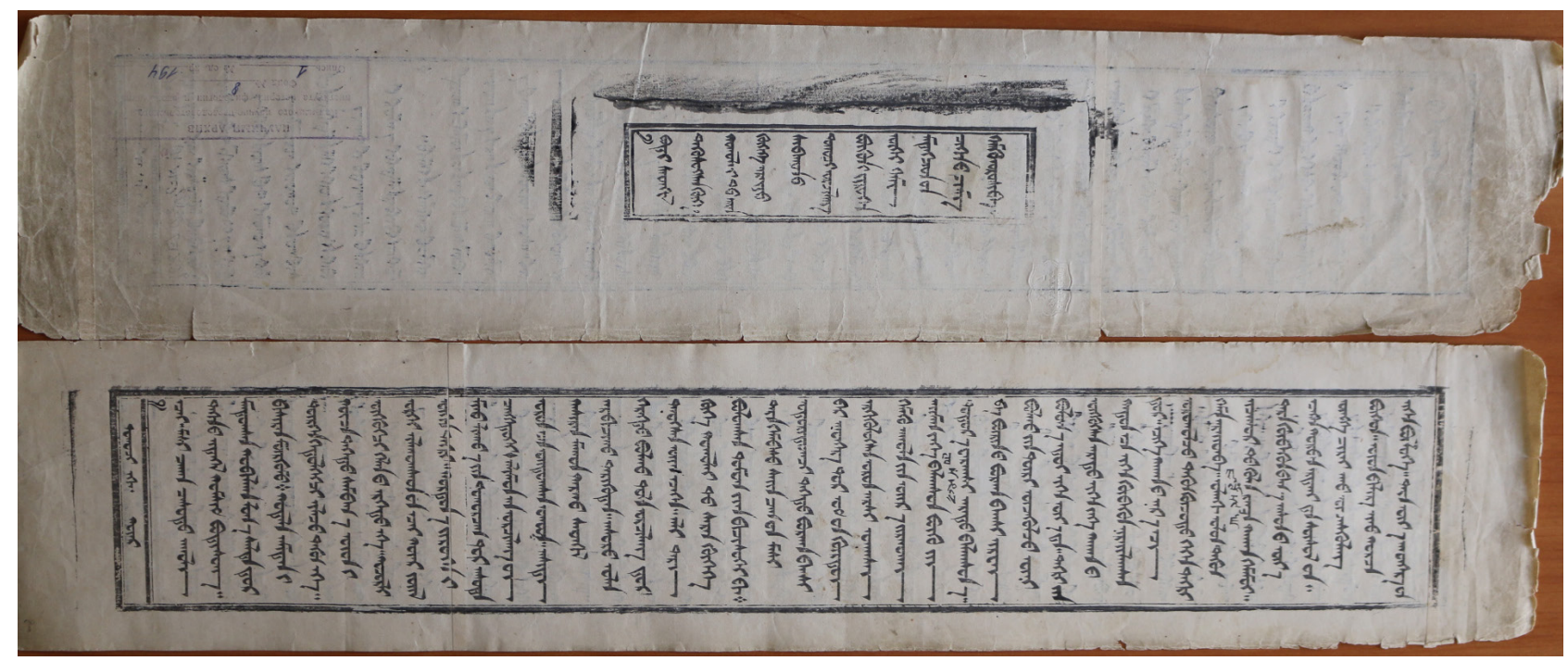

Фото 3. Титульный лист и лист 2 а ксилографа на монгольском языке из Научного архива КалмНЦ РАН (иифр Ф-8, опись 1, ед.хр. 194).

Photo 3. The title page and page $2 a$ of the xylograph in Mongolian from the Scientific Archive of KalmSC of the RAS (code F-8, inventory 1, unit 194). 


\section{Сопоставительный анализ тибетского и монгольского текстов}

Сопоставительный анализ текстов рукописей и ксилографов на тибетском языке, которые в настоящее время хранятся в самых разных востоковедных центрах и библиотеках, показывает, что все они идентичны и композиционно подразделяются на 9 глав. Приведем названия глав тибетского ксилографа и сопроводим этот перечень названиями глав печатного издания на монгольском языке в транслитерации и переводе.

\begin{tabular}{|c|c|c|}
\hline & Тиб. & Монг. \\
\hline I глава & $\begin{array}{l}\text { Yab yum gyi rtogs pa brjod pa mdor bsdus } \\
\text { pa dang I 'phos shing lhums su zhugs pa'i } \\
\text { skabs dang pa'o } \\
\text { ('Глава первая, обобщенно повест- } \\
\text { вующая об истории жизни отца и } \\
\text { матери, а также о том, как был зачат') }\end{array}$ & 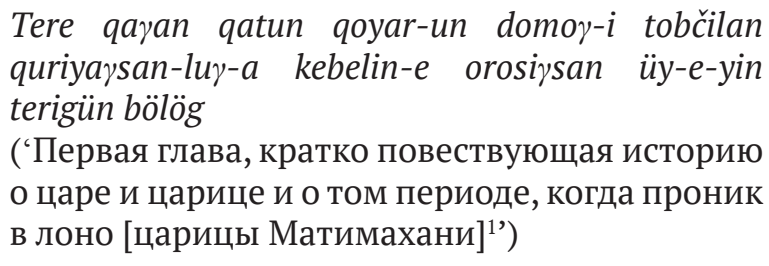 \\
\hline II глава & $\begin{array}{l}\text { sKu byis pa'i skabs dang chos blon gsum } \\
\text { nub phyogs su gshegs pa'i skabs te gnyis } \\
\text { pa'o } \\
\text { ('Вторая глава о младенчестве, а } \\
\text { также об изгнании трех сановников в } \\
\text { западном направлении') }\end{array}$ & 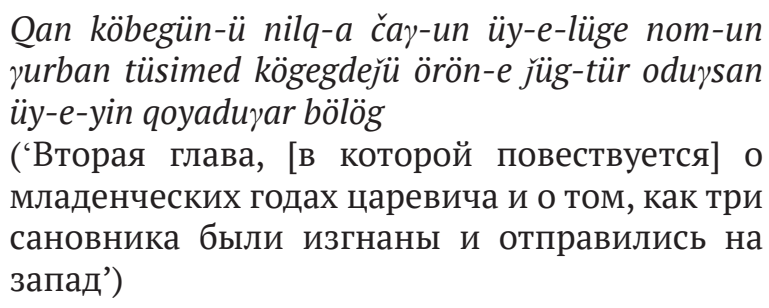 \\
\hline III глава & $\begin{array}{l}\text { sKu gzhon nu'i skabs dang I grongs 'jug } \\
\text { sbyangs shing yum zhi bar gshegs pa'i } \\
\text { skabs te gsum pa'o } \\
\text { ('Третья глава о молодых годах, об } \\
\text { обучении способности переноса } \\
\text { сознания (вхождения в тела умерших } \\
\text { существ) и о кончине матери') }\end{array}$ & 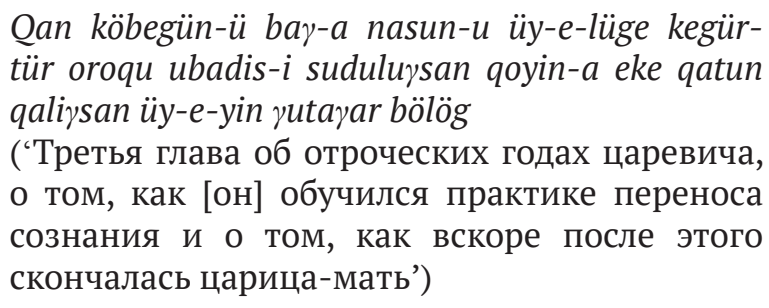 \\
\hline IV глава & $\begin{array}{l}\text { Grong 'jug gi rkyen gyis bya'i lus su gyur pa } \\
\text { dang sprul pa'i bya dang mjal ba sogs kyi } \\
\text { skabs te bzhi pa'o } \\
\text { ('Четвертая глава о том, как посред- } \\
\text { ством способности вхождения в } \\
\text { тела умерших существ обрел тело } \\
\text { птицы, а также встреча с птицей- } \\
\text { перерожденцем и проч.') }\end{array}$ & 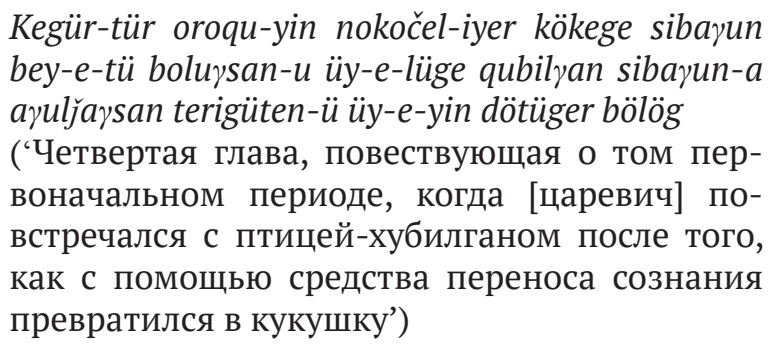 \\
\hline$V$ глава & $\begin{array}{l}\text { Bya rnams la thog mar chos gsungs pa bla } \\
\text { ma dri med dpal ldan las thun mong ma } \\
\text { yin pa'i gdam pa dang lung bstan thob pa'i } \\
\text { skabs te lnga pa'o } \\
\text { ('Пятая глава о преподании птицам } \\
\text { основ учения, о получении от } \\
\text { ламы Дримедпала общих и особых } \\
\text { наставлений и пророчеств') }\end{array}$ & 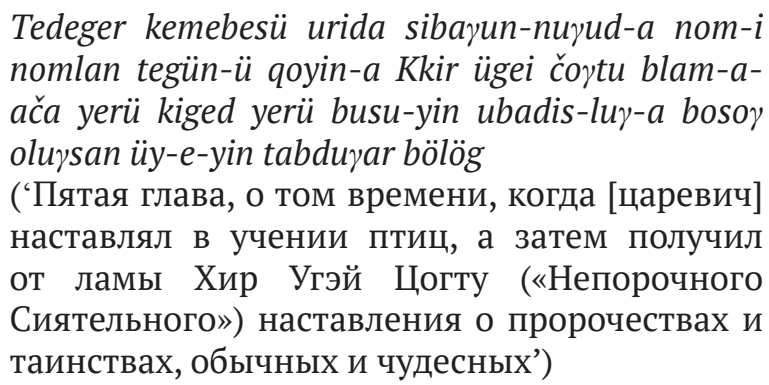 \\
\hline
\end{tabular}

${ }^{1}$ Здесь и далее в таблице в квадратных скобках мы приводим пояснения к тексту. 


\begin{tabular}{|c|c|c|}
\hline VI глава & $\begin{array}{l}\text { 'Phags pa thugs rje chen po yab yum gyis } \\
\text { lung bstan cing dge 'dun rnams kyis shing } \\
\text { rtar gdan drangs pa dang rgyal bu brdzun } \\
\text { ma pham par mdzad cing gser bzang ma } \\
\text { dang slar mjal ba sogs 'thor bu sna tshogs } \\
\text { gyi skabs te drug pa'o } \\
\text { ('Шестая глава о пророчестве Авало- } \\
\text { китешвары и его женской ипостаси } \\
\text { [Тары], о водружении общиной мо- } \\
\text { нахов на деревянную колесницу, по- } \\
\text { беде лже-царевича, новой встрече с } \\
\text { Сэрсанмой и многими другими') }\end{array}$ & 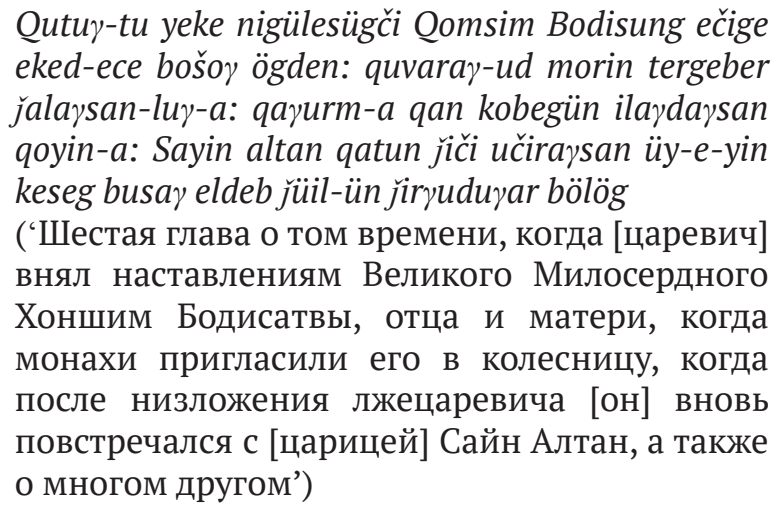 \\
\hline VII глава & $\begin{array}{l}\text { Rang gi 'dul rnams la tshigs bcad glu } \\
\text { dbyangs su sdebs pa rgya mtsho lta bu'i } \\
\text { mang nas । blo dman gyis go bde zhing I } \\
\text { deng dus nye bar 'kho ba 'ga' zhig smras } \\
\text { pa'i skabs te bdun pa'o } \\
\text { ('Седьмая глава о произнесении тем, } \\
\text { кого [следует усмирить], из мно- } \\
\text { жества - подобно океану - ме- } \\
\text { лодичных стихов, легких для по- } \\
\text { нимания, а также о необходимых в } \\
\text { данный момент вещах) }\end{array}$ & 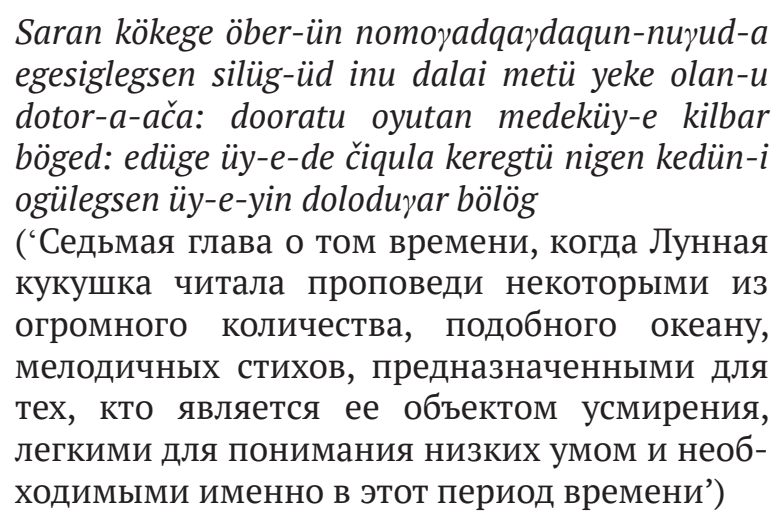 \\
\hline VIII глава & $\begin{array}{l}\text { Slar Varanāsir 'dzom ste bla ma dri med } \\
\text { pa'i dpal gyi zhal mjal zhing lung bstan } \\
\text { thob pa sogs kyi skabs te brgyad pa'o } \\
\text { ('Восьмая глава о повторной встрече } \\
\text { в Варанаси, о встрече с ламой Дри- } \\
\text { медпалом и получении от него на- } \\
\text { ставлений’) }\end{array}$ & 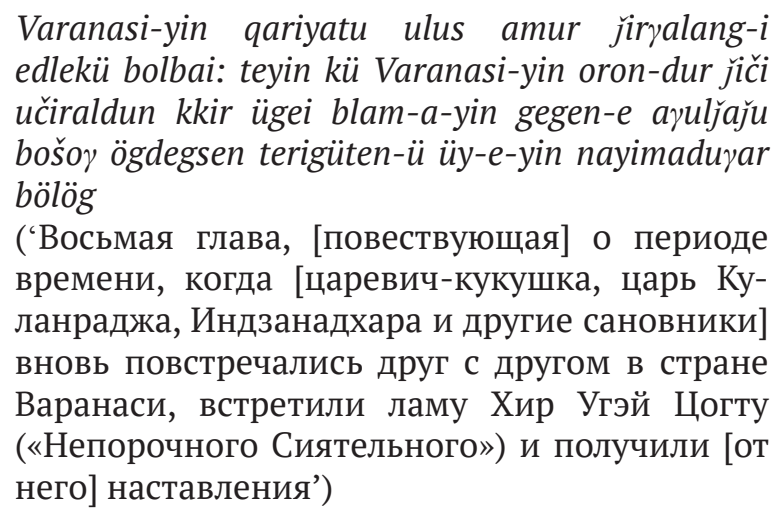 \\
\hline IX глава & $\begin{array}{l}\text { mThar sku gshegs pa'i skabs te dgu pa'o } \\
\text { (‘Девятая глава о кончине’) }\end{array}$ & $\begin{array}{l}\text { Ecüs-tür töröl aralj̈ijsan üy-e-yin yisüdüger bölög } \\
\text { (‘Девятая глава, [повествующая] о периоде, } \\
\text { когда в конце [жизни царевич-кукушка] } \\
\text { поменял рождение’) }\end{array}$ \\
\hline
\end{tabular}

Приведенные выше перечни глав тибетского текста и монгольского перевода показывают, насколько тонко в последнем передаются нюансы, детали исходного текста. Монгольский переводчик добавляет лишь отдельные слова и частицы для уточнения своего перевода.

В данной публикации мы сочли возможным представить для сравнения фрагмент из тибетского текста, его монгольский перевод, а также соответствующий английский перевод Геше Вангъяла. 


\begin{tabular}{|c|c|c|}
\hline Тиб. & $\begin{array}{c}\text { Монг. перевод } \\
\text { Дай гуши Агвандампила }\end{array}$ & $\begin{array}{l}\text { Англ. перевод } \\
\text { Геше Вангъяла }\end{array}$ \\
\hline $\begin{array}{l}\text { dkon mchog gsum la snying nas } \\
\text { mgos phyag 'tshal // } \\
\text { sdug bsngal mun pa sel bar byin } \\
\text { gyis rlobs // } \\
\text { gting mtha' med pa'i 'khor ba'i } \\
\text { rgya mtsho 'dir // } \\
\text { nyon mongs sdug bsngal na kras } \\
\text { rab gtses pa'i // } \\
\text { bdag sogs 'gro rnams srid las } \\
\text { bsgral du gsol // } \\
\text { ('Всем сердцем поклоняюсь } \\
\text { Трем драгоценностям! } \\
\text { Даруйте благословение для } \\
\text { того, чтобы рассеять тьму } \\
\text { страданий. } \\
\text { Соизвольте освободить из } \\
\text { сансары меня и других жи- } \\
\text { вых существ, которые под- } \\
\text { верга ются неимоверным } \\
\text { истязаниям морского чудо- } \\
\text { вища в этом бездонном } \\
\text { океане бесконечного круго- } \\
\text { ворота страданий от помра- } \\
\text { чений') } \\
\text { (Вуапя сhиь, л. 55б-56а) }\end{array}$ & 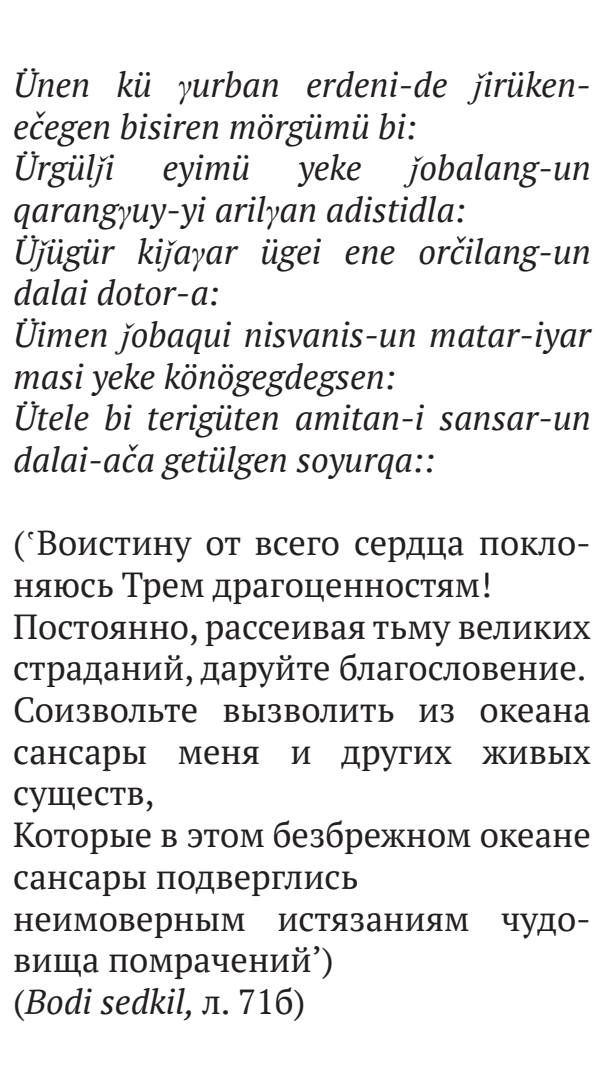 & $\begin{array}{l}\text { I bow down with all my heart to } \\
\text { the Three Jewels; } \\
\text { I beg you to clear away this dark } \\
\text { misery. } \\
\text { Please, rescue me and all other } \\
\text { beings } \\
\text { From this bottomless ocean of } \\
\text { cyclic existence } \\
\text { Wherein we are tortured by those } \\
\text { serpents, } \\
\text { The miseries brought on by our } \\
\text { fettering passions' } \\
\text { ('Я всем сердцем поклоняюсь } \\
\text { Трем драгоценностям! } \\
\text { Я молю вас о том, чтобы ус- } \\
\text { транили тьму страданий. } \\
\text { Пожалуйте спасение мне и } \\
\text { всем живым существам от } \\
\text { бездонного океана круговорота } \\
\text { жизни, } \\
\text { В котором нас мучают эти } \\
\text { змеи, } \\
\text { Где мы страдаем от наших } \\
\text { страстей') } \\
\text { ('емһе Wапууа, 1982: 86) }\end{array}$ \\
\hline
\end{tabular}

\section{Заключение}

Подводя итог анализу, нам хотелось бы выразить надежду, что данная публикация вызовет интерес к памятнику со стороны широкого круга читателей. Как нам кажется, связи этого произведения с тибетским, монгольским и тувинским фольклором, оригинальной и переводной литературой еще недостаточно изучены, между тем они обещают интересные перспективы.

Со времени издания монгольской версии (малым тиражом) прошло 15 лет, в то время как внимание к этому памятнику возрастает. Возможно, публикация данной статьи позволит решить вопрос о втором издании этого сочинения, являющегося образцом популярного буддизма и ярким примером средневековой литературы Центральной Азии. Подобная публикация могла бы привлечь данные о ксилографическом издании тибетского оригинала памятника из музейного фонда Тувы к дальнейшим археографическим поискам среди тибетских рукописей и ксилографов, хранящихся в библиотеках и архивах.

Факт наличия версий этого письменного памятника в фондах Калмыкии и Тувы свидетельствует об общих истоках религиозных текстов. Письменные источники проникали в среду лам и мирян из известных буддийских центров. Цель, которую преследовали буддийские проповедники и в среде ойратов и калмыков, и в среде тувинцев, была одна - популяризировать буддийское учение, основные его постулаты, к чему привлекались тексты с занимательным сюжетом, каковым и является «Повесть о Лунной кукушке» (на тибетском и монгольском языках).

\section{СПИСОК ЛИТЕРАТУРЫ}

Бичелдей, У. П. (2011) Собрание буддийских рукописей и ксилографов в фондах Национального музея Республики Тыва как памятники духовной культуры тувинского народа // Память мира: историко- 
документальное наследие буддизма. Мат-лы Межд. науч.-практ. конф./ отв. ред. В. В. Минаев. М. : РГГУ. 359 c. С. $228-233$.

Востриков, А. И. (1962) Тибетская историческая литература. М. : Издательская фирма «Восточная литература». 427 с.

Мирзаева, С. В. (2018) «Арья-бхадрачарья-пранидхана-раджа» («Зангчо монлам») в письменной традиции буддизма ваджраяны // Вестник Калмыцкого института гуманитарных исследований РАН. № 2 (36). С. 131-143.

Мирзаева, С. В., Тувшинтугс, Б. (2019) Монголоязычные версии «Сутры о восьми светоносных» (монг. Найман гэгээн, калм. Нәәмн гегән): об истории изучения и списках в фондохранилищах России // Oriental Studies. № 44(4). С. 716-727.

Монголын уран зохиолын тойм [История монгольской литературы] (1976). 2-р боть. Улаанбаатар : Шинжлэх ухааны академийн хэвлэл. 672 х. (На монг. языке).

Музраева, Д. Н. (2018) Коллекция тибетских и монгольских письменных источников Калмыцкого научного центра РАН, поступившая от Э. Б. Убушиева. Штрихи к портрету фондообразователя по дарственным записям // Вестник архивиста. № 4. С. 1206-1216.

Музраева, Д.Н., Сумба, Р.П. (2019) О ксилографическом сборнике буддийских текстов на монгольском языке из Национального музея Тувы [Электронный ресурс] // Новые исследования Тувы. № 2. URL: https://nit.tuva.asia/nit/article/view/852 (дата обращения: 23.06.2019). DOI: 10.25178/nit.2019.2.12

Повесть о Лунной кукушке. Монгольская версия. Факсимиле ксилографа / предисловие, транслитерация, перевод, комментарии, глоссарий и приложения Д. Н. Музраевой (2004) / отв. ред. И. В. Кульганек / «Письменное наследие народов Центральной Азии». Вып. І. Элиста : АПП «Джангар». 576 с.

Скородумова, Л. Г. (2017) Рукописное наследие В. Инжинаша: «Повесть о лунной кукушке» // Культурное наследие монголов: рукописные и архивные собрания Санкт-Петербурга и Улан-Батора. III Межд. конф. при поддержке Президента Монголии (Санкт-Петербург, 20-22 апреля 2017 г.). Программа. Тезисы. СПб. ; Улан-Батор : б/и. 110 с. С. 84.

Сумба, Р. П. (2019) Письменные источники на тибетском языке из фондов Национального музея Тувы [Электронный ресурс] // Новые исследования Тувы. № 2. URL: https://nit.tuva.asia/nit/article/ view/850 (дата обращения: 23.06.2019). DOI: 10.25178/nit.2019.2.11

Успенский, В. Л. (2011) Тибетский буддизм в Пекине. СПб. : Студия «НП Принт». 368 с.

Цэрэнсодном, Д. (1987) Монгол уран зохиол (XIII-XX зууны эхэн) [Монгольская литература (XIII начало XX в.)]. Улаанбаатар : БНМАУ-ын ардын Боловсролын Яамны Сурах бичиг, сэтгүүлийн нэгдсэн редакцин газар. 439 с. (На монг. языке).

Bakaeva, E. P. (2014) Research on the History of Buddhism in Kalmykia at the Present Stage // Anthropology \& Archeology of Eurasia. Vol. 53. Iss. 4. Pp. 21-46. (На англ. яз.)

Geshe, Wangyal (1982) The Prince Who Became a Cuckoo: A Tale of Liberation / translated and edited by Geshe Wangyal. NY, Theatre Arts Books Publ. 200 p.

Tibetische Handschriften und Blockdrucke (1981) Teil 8 (Sammlung Waddell der Staatsbibliothek Preussischer Kulturbesitz Berlin) beschrieben von Dieter Schuh. Wiesbaden, Franz Steiner Verlag GMBH. $394 \mathrm{p}$.

Дата поступления: 26.08.2019 2.

\section{REFERENCES}

Bicheldei, U. P. (2011) Sobranie buddiiskikh rukopisei i ksilografov v fondakh Natsional'nogo muzeya Respubliki Tuva kak pamyatniki duhovnoi kul'tury tuvinskogo naroda [The collected Buddhist manuscripts and xylographs of the National Museum of the Tuva Republic as monuments of spiritual culture of the Tuvan people]. In: Pamyat' mira: istoriko-dokumental'noe nasledie buddizma [Memory of the world: historical and documentary heritage of Buddhism]. Proceedings of the International Scientific Conf. / ed. by V. V. Minaev. Moscow, Russian State University for the Humanities. 229 p. Pp. 228-233. (In Russ.).

Vostrikov, A. I. (1962) Tibetskaya istoricheskaya literatura [Tibetan historical literature]. Moscow, Vost. Lit. 427 p. (In Russ.). 
Mirzaeva, S. V. (2018) «Ar'ya-bhadrachar'ya-pranidhana-radzha» («Zangcho monlam») v pis'mennoi traditsii buddizma vadzhrayany [The written tradition of Vajrayana Buddhism: Ärya Bhadracarya Pranidhāna Rāja (Tib. Bzang spyod smon lam)]. Bulletin of the Kalmyk Institute for Humanities of the Russian Academy of Sciences (Oriental Studies), vol. 36, no. 2, pp. 131-143. (In Russ.).

Mirzaeva, S. V. and Tuvshintugs, B. (2019) Mongoloyazychnye versii «Sutry o vos'mi svetonosnyh» (mong. Najman gegeen, kalm. Nəəmn gegən): ob istorii izucheniya i spiskah $v$ fondohranilishchah Rossii [Mongollanguage versions of the Sutra of the eight light-bearers (Mong. Naiman Gegen, Kalm. Naemn gegen): about the history of studying and lists in the Russian storage facilities]. Oriental Studies, no. 44(4), p.p 716-727. (In Russ.)

Mongolyn uran zohiolyn toym [History of Mongolian Literature] (1976). Vol. 2. Ulaanbaatar, Mong. Acad. of Sc. 672 p. (In Mong.).

Muzraeva, D. N. (2018) Kollektsiya tibetskikh i mongol'skikh pis'mennykh istochnikov Kalmytskogo nauchnogo centra RAN, postupivshaya ot E. B. Ubushieva. Shtrikhi k portretu fondoobrazovatelya po darstvennym zapisyam [The collection of Tibetan and Mongolian written sources donated to the Archive of the Kalmyk Scientific Center of the RAN by E. B. Ubushiev. Using donation inscriptions to touch up the portrait of donator]. Herald of an Archivist, no. 4, pp. 1206-1216. (In Russ.).

Muzraeva D. N. and Sumba R. P. (2019) O ksilograficheskom sbornike buddiiskikh tekstov na mongol'skom yazyke iz Natsional'nogo muzeya Tuvy [On a xylographic compilation of Buddhist texts in Mongolian language from the National Museum of the Republic of Tuva]. The New Research of Tuva, no. 2 [online] Available at: https://nit.tuva. asia/nit/article/view/852 (access date: 23.06.2019). DOI: 10.25178/nit.2019.2.12. (In Russ.).

Povest' o Lunnoi kukushke. Mongol'skaya versiya. Faksimile ksilografa / Predislovie, transliteracija, perevod, kommentarii, glossarij i prilozhenija D. N. Muzraevoi [The Tale of the Moon Cuckoo. Mongolian version. Facsimile of the xylograph, introduction, transliteration, translation, commentary, glossary and indices by D. N. Muzraeva] (2004). Ed. by I. V. Kulganek. ('Written heritage of Central Asian Peoples'. Is. I). Elista, Dzhangar. 576 p. (In Russ. and Mong.).

Skorodumova, L. G. (2017) Rukopisnoe nasledie V. Inzhinasha: «Povest' o lunnoi kukushke» [The manuscript heritage of V. Inzhinash: 'The Tale of the Moon Cuckoo']. In: Kul'turnoe nasledie mongolov: rukopisnye i arkhivnye sobraniya Sankt-Peterburga i Ulan-Batora. III Mezhd. konf. pri podderzhke Prezidenta Mongolii [Cultural Heritage of the Mongols: manuscript and archival collections of St. Petersburg and Ulaanbaatar. $3^{d}$ International Conference with the support of the President of Mongolia]. Program. Theses. St. Petersburg, Ulaanbaatar. 110 p. P. 84 . (In Russ.).

Sumba, R. P. (2019) Pis'mennye istochniki na tibetskom yazyke iz fondov Natsional'nogo muzeya Tuvy [Written sources in Tibetan language in the collections of the National Museum of the Republic of Tuva]. The New Research of Tuva, no. 2. [online] Available at: https://nit.tuva.asia/nit/article/view/850 (access date 23.06.2019). DOI: 10.25178/ nit.2019.2.11. (In Russ.).

Uspensky, V. L. (2011) Tibetskiy buddizm v Pekine [Tibetan Buddhism in Beijing]. St. Petersburg, NP-Print. 368 p. (In Russ.).

Tserensodnom, D. (1987) Mongol uran zohiol (XIII-XX zuuny 'eh'en) [Mongolian literature (18 ${ }^{\text {th }}-$ beginning of the $20^{\text {th }}$ century)]. Ulaanbaatar, Ministry of National Education of MPR. 439 p. (In Mong.).

Bakaeva, E. P. (2014) Research on the History of Buddhism in Kalmykia at the Present Stage. Anthropology \& Archeology of Eurasia, vol. 53, iss. 4, pp. 21-46.

Geshe, Wangyal (1982) The Prince Who Became a Cuckoo: A Tale of Liberation. Transl. and ed. by Geshe Wangyal. New York, Theatre Arts Books Publ. 200 p. (In Eng.).

Tibetische Handschriften und Blockdrucke [Tibetan manuscripts and xylographs] (1981) Part 8 (Waddell Collection of State Library, Prussian Cultural Heritage Foundation, Berlin) comp. by D. Schuh. Wiesbaden, Franz Steiner Verlag GmbH. 394 p. (In Germ.).

Submission date: 26.08 .2019$. 